\title{
EMPLOYMENT IN THE PUBLIC SECTOR
}

\author{
LORENZO FORNI \\ RAFFAELA GIORDANO
}

\section{CESIFO WORKING PAPER NO. 1085 \\ CATEgORY 1: Public Finance \\ NOVEMBER 2003}

Presented at Venice Summer Institute, Workshop on TAX POLICY AND LAOBUR MARKet Performance, July 2003

\footnotetext{
An electronic version of the paper may be downloaded - from the SSRN website: www.SSRN.com

- from the CESifo website: www.CESifo.de
} 


\title{
EMPLOYMENT IN THE PUBLIC SECTOR
}

\begin{abstract}
This paper presents a model of wage-employment determination in private and public sectors, which allows us to analyze the effects of different institutional arrangements on labor market equilibria. In particular, it focuses on how different degrees of coordination in decision processes affect hiring and wage setting outcomes. Cooperation in unions' behavior results in wage increases and employment reduction in the private sector, whereas it induces wage moderation and employment expansion in the public sector. Not surprisingly, if public decision units do not fully internalize the aggregate budget constraint in their hiring processes, the public sector wage bill and the level of taxation increase, thus enhancing the crowding out effect on private employment. Such effect appears to be stronger in the presence of encompassing union behavior. An empirical analysis performed on a sample of OECD countries in the period 1960-2000 seems to support the main predictions of the model.
\end{abstract}

JEL Classification: E24, H50, H72, J45, J51.

Keywords: public employment, wage bargaining, decentralization.

\author{
Lorenzo Forni \\ Banca d'Italia \\ Research Department \\ Via Nazionale, 91 \\ 00184 Roma \\ Italy \\ forni.lorenzo@insedia.interbusiness.it
}

\author{
Raffaela Giordano \\ Banca d'Italia \\ Research Department \\ Via Nazionale, 91 \\ 00184 Roma \\ Italy \\ giordano.raffaela@insedia.interbusiness.it
}

The views expressed in this paper are those of the authors and do not imply any responsibility of the Bank of Italy. We wish to thank Steve Nickell, Dieter Boes, Alberto Bennardo and participants in seminars at Bank of Italy, Italian Economic Association 2002 (Ferrara), CESIfo Summer Institute 2003 (Venice), European Economic Association 2003 (Stockholm) and International Institute of Public Finance 2003 (Prague). 


\section{Introduction}

This paper builds on a set of stylized facts to set up a model of wage-employment determination in private and public sectors, which allows to analyze the effects of different institutional arrangements on the labor market equilibrium. In particular, it focuses on how different degrees of coordination in governments' and unions' decision processes affect hiring and wage setting outcomes. The degree of coordination influences governments' and unions' behavior in at least two ways: first, decisional units (at the central or local government level) negotiating about employment and wages in the public sector may not internalize the nationwide budget constraint; second, the degree of coordination in wage negotiations may influence the extent of cooperation between the public sector unions and the ones representing employees in the private sector. We believe that these issues are very relevant at a time in which several European countries are delegating more powers to regional and local authorities while at the same time the traditional wage negotiating rules are under discussion or being revised.

Our main focus is on public employment. However, employment levels and earnings in the public sector are related to the private sector ones in several ways. In the first place, resources to pay wages to public employees are drawn from the private sector and to a large extent from private sector labor earnings. Therefore, a growing private sector economy should allow for higher wages and employment levels also in the public sector. Secondly, in their hiring processes governments may take into account not only the needs related to public production but also considerations about the developments of the overall labor market, as the level of the unemployment rate or its variability over time. A third important reason regards wage setting: public sector unions may coordinate their activity and cooperate with private sector unions; in countries with a very centralized wage negotiation process, usually the same unions negotiate for both public and private sector wages.

Wage and employment characteristics in the public sector differ significantly from those in the private sector. Table $1 \mathrm{~A}$ in the appendix shows that the number of public employees, both as a share of total employed and as a share of dependent employees, has been growing significantly between 1960 and the end of 1980s in the major European countries; in the last decade, with the exception of France, these countries have kept constant or reduced the share of public employment. ${ }^{1}$ These developments can be traced back to the expansion of the welfare state and of the local authorities

\footnotetext{
${ }^{1}$ Comparison of the levels of public sector employees is made difficult by the problems related to the different definitions of public sector. For example, in countries where a significant part of hospitals and/or schools are private - or even when they are publicly owned, but are classified outside the general government, because they are privately managed - the costs borne by the government (as salaries) may be classified in the budget accounts under categories other than the wage bill, such as social payments. On this issue a very detailed, although dated, survey is Heller and Tait (1983).
} 
in European countries during the 1960s and the 1970s. During the '90s the constraints related to fiscal consolidation have played a role. As for the wage developments, studies have generally found a positive wage premium for public sector employees; they typically use microeconomic data in order to control for the quality and composition of public relative to private sector employees (Gregory and Borland, 1999). Portugal and Centeno (2001) use the 1995 wave of the Europen Union Household Panel to document the extent of the public sector wage premium for thirteen european countries.

The peculiarity of the public employer's ultimate goal is the natural candidate for the cause of the differences between public and private sectors briefly documented. Whereas the private sector employer can be reasonably assumed to be a profit maximizer, there are two main theoretical approaches in the literature to understanding how public employer's decisions will be made. ${ }^{2}$ One approach treats public sector decision-makers as making choices to achieve socially optimal outcomes; the alternative approach introduces some personal objective of the politicians. Public sector decision-makers who seek to maximize social welfare may have both efficiency and equity goals. The efficiency goal can be manifested in different ways. It may simply imply that politicians or bureaucrats choose employment and earnings to minimize the costs of production of output in the public sector. Or it may mean that employment is set in a way that is intended to resolve labor market imperfections that exists elsewhere in the economy.

In this paper we assume that the public sector employer has primarily an efficiency goal. This goal implies that, once the union has chosen the wage, he sets employment to maximize the profit associated with the public production. ${ }^{3}$ Furthermore, unionization in the private sector makes the level of privately-chosen work and production too low. Reducing the unemployment rate in the economy is also part of the government efficiency goal. ${ }^{4}$

Public sector employment and compensation levels will affect private sector ones through both the amount of taxes levied on the private sector labor income and, to the extent unions in the two sectors cooperate, the wage setting process. In the end, the overall equilibrium in the labor market will significantly depend upon the determinants of wages and employment in the public sector.

The paper is organized as follows. Section 2 contains a review of the literature. Section 3 presents the model. Section 4 solves for the equilibrium in a fragmented public employees hiring

\footnotetext{
${ }^{2}$ For a discussion on the argument see Gregory and Borland (1999) and references therein.

${ }^{3}$ Measuring the efficiency achieved in the public sector production activity by the profit may not be considered appropriate. However, it enables us to easily compare the outcomes obtained for the two sectors (private and public), while not affecting the qualitative features of the model.

${ }^{4}$ In our model the case of a competitive labor market in the private sector can be thought of as an extreme case. Under such a circumstance the government's additional goal concerning the overall level of employment in the economy, which makes the public employer distinguishable from the private sector one, vanishes and the problem becomes trivial.
} 
setup, both in the presence of sector-specific unions and in the presence of an encompassing one; section 5 considers the alternative situation, in which public sector units coordinate their hiring decisions and take into account the aggregate budget constraint. Section 6 presents a numerical simulation and section 7 shows some empirical evidence. Section 8 concludes.

\section{Review of the literature}

Given the relevance, both in terms of levels and variations, of public employment is somehow surprising that: i) there are very few studies that try to deepen the understanding of the characteristics of public sector employment; ii) analyses of the labor market usually tend to ignore the effects on the overall employment levels of the interactions between public and private sector labor demand.

In each of the last two issues of the Handbook of Labor Economics there is a chapter on Public Sector Labor Markets. In the 1986 Handbook the authors (Ehrenberg and Schwarz) discuss extensively the reason for having a separate chapter on public sector employment. It emerges that public employment in the US had been growing very quickly between 1950 and 1975, together with unionization among public employees, and that public sector wages were higher than comparable private sector ones over the same period. This evidence spurred a relevant amount of research aimed at assessing the extent and the reasons of the public sector wage premium. In particular, the concern was that unionization would lead to higher wages and, therefore, higher public expenditure. Overall, the findings on the US experience pointed to a limited wage premium due to union membership or collective bargaining coverage (typically of the order of 10\%) and suggested that the effects of unions on wages were lower in the public sector that in the private one. Also, the demand elasticities for public sector workers were found to be negative for most categories of labor; however, there was some evidence, although not strong, that the elasticities were lower in absolute value than those estimated for the private sector.

In the 1999 Handbook the authors (Gregory and Borland) analyze a wider set of issues and take also a cross-country perspective. The chapter stresses the importance of using microeconomic data to control for composition and skill heterogeneity in analyzing the public sector wage premium. The premium, which is found in most analysis (even if of a smaller size when using microeconomic data) is put in relation to the degree of unionization. However, the way unions affects the wage premium is not entirely understood. The monopoly union model, for example, predicts that unionization

increases wages at the expense of lower employment; the latter prediction is not supported by the empirical evidence.

The negative effect of unionization on employment levels can be mitigated by two factors. 
First, unions may be able to shift out the demand curve for labor through political pressure; second, unions may be able to implement efficient bargaining where both wage and employment can increase relative to the situation that would prevail in the absence of unionization. ${ }^{5}$ One attempt to distinguish between these two explanations is in O'Brien (1994). He found, for US police and fire services employees, that political activity has a significant positive effect on employment, whereas collective bargaining has an insignificant or negative effect. This finding would support the hypothesis that union effects on employment operate through a demand-shift effect rather than through the bargaining over wages and employment (efficient bargaining). Gregory and Borland also show that trade union density ${ }^{6}$ is higher for public sector than for private sector employees in most developed countries. In some countries, such as the US, the increase in public sector union density since the 1960s has contrasted with decreases in private sector union density. Institutional and legal factors seem the most important ones in explaining these developments.

Few papers analyze the various form of interaction between public and private sector employment levels. A notable exception is Holmlund (1993 and 1997). Holmund (1993) proposes an explanation for the public sector wage premium based on the idea that any wage increase for the public sector employees is borne mainly by private sector employees through an increase in taxation. This externality would lead the public sector union, only concerned about public employees, to ask for higher wages. Holmund (1997) analyzes a model where an increase in public wage or employment, by increasing the reservation utility of private sector workers and their bargaining power, leads to an increase in the private sector wage and a reduction in the private sector employment. Both models suggest that there may be a negative relationship between public and private sector employment. The partial crowding out of private employment by employment in the public sector may come from higher taxes and higher reservation wages. On this issue there is some empirical evidence. Boeri, Nicoletti and Scarpetta (2000) report evidence of a partial crowding out of about $30 \%$. They regress overall employment levels on public employment and a series of control variables obtaining an estimate of 0.7 for the public employment coefficient. A similar approach is taken by Algan, Cahuc and Zylberberg (2002). They find an even stronger crowding out effect of public employment.

As in the papers by Holmund (1993 and 1997), we assume that the interaction between public and private sector employment levels hinges on the idea that wages for the public sector employees are financed by taxes on private sector labor income. In our model, wages in the two sectors are set by monopoly unions, which can either act cooperatively or uncooperatively across sectors.

\footnotetext{
${ }^{5}$ On this see the classical work of McDonald and Solow (1981).

${ }^{6}$ Union density is measured by dividing union members by the number of wage- and salary-earners in total employment.
} 
While the employer in the private sector is assumed to be a profit maximizer, the choice of the public employer's objective function relies on both theoretical considerations and empirical findings. The existing evidence suggests that, for most categories of labor in the public sector, employment exhibits a relatively low wage elasticity. Furthermore, a public sector wage premium shows up for most countries and periods of analysis. These two facts can be explained by a model in which the public employer is concerned not only about profits but also about the overall level of employment in the economy. The presence of this additional objective, as we will see later in the paper, may either generate a wage premium or not depending on the institutional setup (i.e., the degree of coordination in both hiring and wage setting processes); it definitely decreases the wage elasticity of the demand for public employment. The weak relationship between wage and employment that is observed in the data may also be due to the ability of unions to outward shift the labor demand curve; this may be achieved either by exerting some sort of political influence or, as in our paper, by strategically setting wages in the two sectors.

\section{The model}

The economy consists of a large number of productive units: $n$ of them are privately owned and all identical; $n_{g}$ are public and all identical to each other. Public units can be thought of as decisional units of the central government or local governments. The private sector is represented by standard profit-maximizer firms. In both public and private sectors wages are set unilaterally by a monopoly union.

Given the wage quoted by the union, each employer chooses the number of workers so as to maximize its utility function. Although hiring decisions in the public sector may occur at the unit level, taxes are assumed to be set by the central government to satisfy an aggregate budget constraint; they are imposed on the private sector labor income and serve to finance the expenditure for public employment.

The situation can be described by a noncooperative dynamic game between the private and the public sectors, where each sector is represented by firm-union pairs. The equilibrium concept we focus on is the perfect Nash solution: negotiations in both sector occur simultaneously, each sector taking as given what happens in the other one. ${ }^{7}$

\footnotetext{
${ }^{7}$ We can assume instead that the game between private and public sectors' unions is Stackelberg (with the union in the public sector being the leader), rather than Nash. This setup better characterizes a situation, perhaps more realistic in some economies, in which the behavior of unions in the private sector is somehow affected by the agreements reached in the public sector. In the case of fragmented governments, in which by assumption the overall budget constraint is not internalized by the individual government unit, the Stackelberg equilibrium coincides with the one obtained under Nash behavior. In contrast, when the government is centralized (that is, when each decisional unit takes into account the effects that changes in the public wage bill may have on the level of taxation and, hence, on
} 
The timing of the game is the following. In period 1 unions in private and public sectors set the wage in their own sector that is going to prevail until the end of the game. In period 2 private firms and public units observe the wage quoted by the unions and choose the volume of employment. The analysis will focus on symmetric equilibria where all firm-union pairs have the same expectations and make the same choice. We will consider different degrees of coordination, concerning both governments' and unions' decision processes.

Coordination in government's behavior is assumed to entail acknowledgement, during the hiring process at the unit level, of the central government budget constraint, which, by assumption, must hold for the economy as a whole only. We define such a setup a centralized-government economy. ${ }^{8}$ In contrast, in a fragmented setting hiring decisions are taken by each decisional unit (at the central or local level) without taking into account the effect that an increase in the public wage bill may have on the overall level of taxation and, consequently, on the private sector after-tax wage and employment.

Coordination in unions' behavior is assumed to imply cooperation between unions in public and private sectors. Under uncoordinated behavior each union is assumed to care only about workers in its own sector and to set the wage taking the wage rate in the other sector as parametric to its wage choice. In contrast, under perfect coordination the union confederation chooses wages in public and private sectors to maximize the sum of utilities of employees in both sectors. Cooperation among unions, associated with coordination in government's behavior, results in a Stackelberg strategy: the union confederation sets wages in the two sectors while fully recognizing the government's employment and tax responses.

All situations are summarized in Table 1.

\subsection{The private sector}

The private sector consists of $n$ price-taking identical firms. The representative firm is characterized by a profit function, $F(L)-w(1+\tau) L$, where $F(L)$ is the production function relating output to labor, $w$ is the net wage, $\tau$ is the tax rate on labor income ${ }^{9}$, and the output price is normalized to unity. The technology is given by the logarithm of the Cobb-Douglas production function: ${ }^{10}$

$$
F(L)=A \log L
$$

the private sector after-tax wage and employment) different mechanisms operate in opposite directions and no clear intuition about the consequences from shifting from a Nash to a Stackelberg setup can be easily drawn.

${ }^{8}$ Formally, this situation can be described by having a third player moving in period 0 and imposing the central government budget constraint.

${ }^{9}$ We assume here, without loss of generality, that taxes on labor income increase the labor cost.

${ }^{10}$ In order to rule out negative levels of output, we may impose a constraint on the technology such that $F(L)=$ Alog $L$ for $L>1$ and $F(L)=0$ otherwise. 
Table 1: Degrees of coordination

\begin{tabular}{c|c} 
Fragmented government & Fragmented government \\
and & and \\
non-cooperative unions & cooperative unions \\
\hline Centralized government & Centralized government \\
and & and \\
non-cooperative unions & cooperative unions
\end{tabular}

where $A>0$ is a productivity parameter. Firms maximize profits, taking wages and taxes as given. The demand for labor is thus

$$
L=\frac{A}{w(1+\tau)}
$$

which exhibits constant wage elasticity equal to one.

\subsection{The government}

The representative government, as any other employer in the private sector, is assumed to care about the profit generated by the production of a good. ${ }^{11}$

Unlike employers in private sector, the government is also assumed to be concerned, either for altruistic or for political motives, about the overall level of employment in the economy, that is the sum of private and public sector workers. ${ }^{12}$ In particular, we assume that it wants to keep total employment as close as possible to a target level $\bar{L} .{ }^{13}$ This second argument in the government's utility function should account for the main differences between public and private employers' objectives. Although we are aware that the public employer's concern about total employment does not exhaust all such differences, it enables us to characterize a demand for public employment

\footnotetext{
${ }^{11}$ In this model the issue of how the profit from the government production is used is not explicitely addressed. A possibility is to assume that the revenue from selling the good, together with taxes on private incomes, is used to finance public sector wages. However, if we include the profit in the government budget constraint the results presented in the paper will not change qualitatively. The change will only affect the size of the crowding-out effect of public on private employment.

${ }^{12}$ In this model the presence of a monopoly union makes the level of privately chosen work too low. Therefore the government would value actions that raise the employment level above its natural level.

${ }^{13}$ We assume $\bar{L}$ large enough, so that $\bar{L}-L_{g}-L$ is always greater than zero.
} 
that exhibits, as the empirical evidence seems to suggest, a moderately negative wage elasticity. Other objectives, in addition to profit maximization, would do the job. ${ }^{14}$

Let $L_{g}$ and $w_{g}$ denote the number of employed workers and the wage rate in public sector, respectively. Let $G\left(L_{g}\right)$ be the production function. We assume, as usual, that $G(0)=0$ and $G\left(L_{g}\right)$ is concave. ${ }^{15}$ Then, the representative government's optimal choice of $L_{g}$ responds to the objective of maximizing the value of the following utility function: ${ }^{16}$

$$
U_{g}=G\left(L_{g}\right)-w_{g} L_{g}-\alpha\left(\bar{L}-L-L_{g}\right)^{2}
$$

The parameter $\alpha$ represents the weight that the government assign to the total employment objective. $^{17}$

The central government always satisfies its budget constraint, which implies that taxes raised from workers in the private sector must equal the sum of wages paid to public-sector workers ${ }^{18}$

$$
\tau w L=w_{g} L_{g}
$$

In a coordinated government economy the budget constraint is taken into account in all decision processes; under an uncoordinated hiring setup it only holds ex-post.

\subsection{The union}

The union in the private sector represents $N$ members, all alike. $L$ of them are employed in the private sector and achieve a level of utility $u(w)$. Analogously, the union in the public sector

\footnotetext{
${ }^{14}$ There have been two main approaches in the literature to model the objectives of public sector decision-makers. One approach has been to treat them as being exclusively concerned with achieving efficient outcomes. The alternative approach specifies an objective function which places some weight on personal or political objective. Empirical evidence provides support for both types of theoretical approaches (Gregory and Borland, 1999). Our model attempts to account for both motivations.

${ }^{15}$ While, for expositional simplicity, we choose the logarithmic form for the production function in the private sector, we prefer here to keep the problem as general as possible, and thus not to impose any specific functional form.

${ }^{16}$ Whereas in the centralized government setup the overall unemployment motive is quite natural, in a fragmented context it may be less intuitive. However, both when public units are thought of as local governments or as decisional units (or ministries) of the central government the same problem at the aggregate level applies to each territorial or decisional unit (i.e., the local government or ministry $j$ maximizes $\left.U_{g, j}=G\left(L_{g, j}\right)-w_{g, j} L_{g, j}-\alpha\left(\bar{L}_{j}-L_{j}-L_{g, j}\right)^{2}\right)$. If public units are thought of as local governments, then the target level of employment naturally applies to the geographical area; if instead they are thought of as decisional units of the central government the target level of employment may refer to a specific sector of the economy that the ministry is assumed to be particularly concerned about.

${ }^{17}$ It seems reasonable to assume that the value of this parameter may vary substantially across countries, as different programs for employment protection may be envisaged. In particular, the value should be small in the presence of important unemployment compensation schemes, such as generous social security systems or easily accessible inability pension schemes.

${ }^{18}$ The budget constraint for the aggregate economy is $\tau \sum_{i=1}^{n} w_{i} L_{i}=\sum_{j=1}^{n_{g}} w_{g, j} L_{g, j}$, where the subscripts $i$ and $j$ identify the productive unit. In a symmetric equilibrium, with all identical units, the budget constraint becomes $\tau n w L=n_{g} w_{g} L_{g}$. Without loss of generality we assume $n=n_{g}$.
} 
represents $N_{g}$ members. $L_{g}$ of them are employed in the public sector and achieve a level of utility $u\left(w_{g}\right) \cdot u(x)$ is the standard sort of concave utility function. If not employed a worker achieves a level of utility $\bar{u}$, which can be thought of as the utility from leisure. It is assumed for simplicity that, because of firm-specific abilities or other reasons, there is no mobility of workers between firms. This is a short-cut to avoid a general equilibrium analysis where the agents have to guess the distribution of wages in the rest of the economy.

The unions in the private and in the public sectors wish to maximize $u(w) L+(N-L) \bar{u}$ and $u\left(w_{g}\right) L_{g}+\left(N_{g}-L_{g}\right) \bar{u}$, respectively, which can be written as $[u(w)-\bar{u}] L+N \bar{u}$ and $\left[u\left(w_{g}\right)-\bar{u}\right] L_{g}+N_{g} \bar{u}$. Since $N, N_{g}$ and $\bar{u}$ are treated as data for the purpose of union wage setting the problems can be summarized by saying that unions wish to maximize the membership's aggregate gain from employment, over and above the utility $\bar{u}$ that every member starts with.

Under non-cooperative union behavior, the union in one sector sets the wage taking as given wage and employment in the other sector. That is, the union in the private sector chooses $w$ to maximize

$$
U_{u}^{n c}=[u(w)-\bar{u}] L(w)
$$

where the superscript $n c$ stands for non-cooperative behavior. Analogously, the union in the public sector sets $w_{g}$ to maximize

$$
U_{u, g}^{n c}=\left[u\left(w_{g}\right)-\bar{u}\right] L_{g}\left(w_{g}\right) .
$$

In the presence of cooperative behavior, the encompassing union sets wages in the private and in the public sectors to maximize

$$
U_{u}^{c}=u(w) L(w)+u\left(w_{g}\right) L\left(w_{g}\right)-\bar{u}\left[L(w)+L_{g}\left(w_{g}\right)\right]
$$

where the superscript $c$ stands for cooperative behavior.

In our analysis we focus on a simple monopoly union model, which represents a union as choosing wages subject to a labor demand constraint. More complicated institutional arrangements are necessary for the achievement of "efficient bargains", where the union bargaining activity forces the wage/employment outcome off the labor demand curve to an efficient contracts-type outcome. ${ }^{19}$

\section{The fragmented-government economy}

In this economy both wage setting and hiring processes occur at the unit level, neither the government decisional units nor the unions recognizing the central government's tax response to their

\footnotetext{
${ }^{19} \mathrm{An}$ accurate analysis of different models of union behavior is provided by McDonald and Solow (1981).
} 
choices. The unions may either act cooperatively, setting simultaneously the wage rate in both private and public sectors, or uncooperatively.

The representative government unit chooses $L_{g}$ to maximize utility (3), given $L$. That is, the public employer does not take into account the effect of its employment choice on taxes and, hence, on private employment. The public sector demand for labor is given by the following first-order condition:

$$
G_{\prime}\left(L_{g}\right)-w_{g}+2 \alpha\left(\bar{L}-L_{g}-L\right)=0 .
$$

The first two terms of this equation represent the marginal profit; the last term is the marginal benefit from a reduction in the difference between actual and desired levels of total employment due to an increase in public employment. As long as $2 \alpha\left(\bar{L}-L_{g}-L\right)>0$, that is total employment in public and private sectors is below the desired level, the value of $L_{g}$ that solves this problem is higher than the one that simply maximizes the profit.

Differentiating (8) with respect to $L_{g}$ and $w_{g}$ we obtain the slope of the demand for public employment

$$
\frac{\partial L_{g}}{\partial w_{g}}=\frac{1}{G \prime \prime\left(L_{g}\right)-2 \alpha} .
$$

By virtue of the concavity of the production function, the demand is always decreasing in the wage. The slope depends on the parameter $\alpha$ : the higher $\alpha$, that is the higher the weight that the government assigns to total employment, the lower the sensitivity of labor demand to changes in the wage rate. The intuition is straightforward: the more concerned is the government about discrepancies between actual and desired levels of employment the less reactive it is to profit maximization considerations. For high enough values of $\alpha$ the labor demand in public sector may turn out to be almost unrelated to the wage.

\subsection{Non-cooperative union behavior}

The best wage for the representative union to set is determined in the obvious way by the tangency of an indifference curve with the employer's labor demand curve. Mathematically, in the private sector this amounts to finding the maximum of (5) with respect to $w$, subject to the demand for labor (2). ${ }^{20}$ The equilibrium wage solves the following first-order condition:

$$
u \prime(w) w-[u(w)-\bar{u}]=0,
$$

\footnotetext{
${ }^{20}$ The payoff of the firm from the agreement is its profit and that of the union is the total utility received by its members. Therefore, agreements are generally restricted to be wages for which the profit of the firm is non-negative and the union members' utility is at least $\bar{u}$.
} 
which can be rearranged as

$$
\frac{u \prime(w) w}{u(w)-\bar{u}}-1=0
$$

The first term is the elasticity of the gain from employment, $u(w)-\bar{u}$, with respect to the wage. The second term is the wage elasticity of the demand for labor. The condition is thus that the two elasticities should be equal. The second-order condition is fulfilled by virtue of the concavity of the utility function.

Analogously, the representative union in the public sector sets the wage to maximize (6), subject to the public employer's reaction function, equation (8), taking $L$ as given.

The Lagrangian for the public sector union's problem takes the form

$$
\mathcal{L}=\left[u\left(w_{g}\right)-\bar{u}\right] L_{g}+\lambda\left[G \prime\left(L_{g}\right)-w_{g}+2 \alpha\left(\bar{L}-L_{g}-L\right)\right]
$$

where $\lambda$ is the multiplier associated with the government's demand for labor. The first-order conditions are:

$$
\begin{array}{cc}
L_{g}: & u\left(w_{g}\right)-\bar{u}+\lambda\left[G \prime \prime\left(L_{g}\right)-2 \alpha\right]=0, \\
w_{g}: & u \prime\left(w_{g}\right) L_{g}-\lambda=0, \\
\lambda: & G \prime\left(L_{g}\right)-w_{g}+2 \alpha\left(\bar{L}-L_{g}-L\right)=0 .
\end{array}
$$

Combining equations (13) and (14) and rearranging, we get

$$
\frac{u \prime\left(w_{g}\right) w_{g}}{u\left(w_{g}\right)-\bar{u}}+\frac{w_{g}}{L_{g}\left[G \prime \prime\left(L_{g}\right)-2 \alpha\right]}=0
$$

that implies, as for the private sector, that the wage elasticity of the gain from employment and that of the demand for labor must be equal in equilibrium. Notice however that, in the presence of the same technology in the two sectors, i.e. for $G(L)=F(L)$ : (i) if wages were set equal across sectors, the demand for labor in the public sector would be higher than that in the private sector (i.e., from first-order condition (15), the labor demand shifts up as $\alpha$ increases); (ii) for same levels of employment, the slope of the labor demand in the public sector is lower than that in the private sector (i.e., from equation (9), the slope of the labor demand decreases with $\alpha$ ); it however increases with the level of employment (because of the presence of the term $G \prime \prime\left(L_{g}\right)$ in the denominator). That is, the presence in the government's utility function of the total employment argument may either increase or decrease the wage elasticity of the labor demand. By comparing conditions (11) and (16) it thus follows that in equilibrium both $w_{g}>w$ and $w_{g}<w$ may occur. In particular, whenever the effect on the slope induced by a higher level of employment is small enough a public-sector wage premium arises in our model. 
Let $w^{F n c}$ denote the equilibrium private-sector wage in a fragmented-government economy under non-cooperative union behavior, as given by the solution to equation (11). Then, the equilibrium levels of private employment, $L^{F n c}$, the tax rate, $\tau^{F n c}$, employment and wage in the public sector, $L_{g}^{F n c}$ and $w_{g}^{F n c}$ respectively, are obtained by solving the system of equations (2), (4), (15) and (16), where $w=w^{F n c}$.

\subsection{Cooperative union behavior}

The objective function of a centralized encompassing union is given by equation (7). The relevant Lagrangian for this problem is thus

$$
\mathcal{L}=\left[u\left(w_{g}\right)-\bar{u}\right] L_{g}+[u(w)-\bar{u}] L+\lambda\left[G \prime\left(L_{g}\right)-w_{g}+2 \alpha\left(\bar{L}-L_{g}-L\right)\right]
$$

where $L$ is given by the private sector labor demand equation, (2).

The first-order conditions are now:

$$
\begin{array}{cc}
L_{g}: & u\left(w_{g}\right)-\bar{u}+\lambda\left[G \prime \prime\left(L_{g}\right)-2 \alpha\right]=0, \\
w_{g}: & u \prime\left(w_{g}\right) L_{g}-\lambda=0, \\
w: & u \prime(w) w-[u(w)-\bar{u}]+2 \alpha \lambda=0, \\
\lambda: & G \prime\left(L_{g}\right)-w_{g}+2 \alpha\left(\bar{L}-L_{g}-L\right)=0 .
\end{array}
$$

The only difference between the solutions to this case and the one assuming non-cooperative union behavior regards the first-order condition for $w$. Substituting $\lambda$ from equation (18) into (20) and rearranging, we obtain

$$
\frac{u \prime(w) w}{u(w)-\bar{u}+\frac{2 \alpha}{G \prime \prime\left(L_{g}\right)-2 \alpha}\left[u\left(w_{g}\right)-\bar{u}\right]}-1=0 .
$$

By comparing equations (22) and (11), it shows that the gain from employment under cooperative behavior is reduced, with respect to that under non-cooperative behavior, by the term $2 \alpha\left[u\left(w_{g}\right)-\right.$ $\bar{u}] /\left[G \prime \prime\left(L_{g}\right)-2 \alpha\right]$. This term takes into account the fact that, due to the government's concern about the overall level of employment, an increase in employment in private sector, induced by a decrease in the wage request in the private sector, determines a reduction in public employment, and viceversa. ${ }^{21}$

As a consequence, the cooperative union will always ask a higher wage for the private sector than a non-cooperative one. With respect to the case with non-cooperative union behavior, the

\footnotetext{
${ }^{21}$ More formally, the gain from employment in the private sector for a cooperative union is given by $u(w)-\bar{u}+$ $\left(\partial L_{g} / \partial L\right)\left[u\left(w_{g}\right)-\bar{u}\right]$. Differentiating equation $(21)$ with respect to $L_{g}$ and $L$ we obtain $\partial L_{g} / \partial L=2 \alpha /\left[G \prime \prime\left(L_{g}\right)-2 \alpha\right]$.
} 
equilibrium will be characterized by higher wages and lower employment in the private sector and by lower wages and higher employment in the public sector. ${ }^{22}$ Therefore, cooperation among unions in the two sectors tends to make the public-sector wage premium lower.

\section{The centralized-government economy}

In this economy decisional units of the central and local government coordinate their hiring decisions internalizing the aggregate budget constraint; the union sets wages nationwide, either cooperatively or non-cooperatively across sectors. Both the public employer and the union fully recognize the effect of their choices on the central government budget constraint and, through the equilibrium tax rate, on private employment.

Substituting $\tau$ from the government budget constraint (4) into the private sector labor demand, equation (2), we obtain that, for any given value of $w_{g} L_{g}$, the following relationship must hold in equilibrium

$$
L=\frac{A-w_{g} L_{g}}{w} .
$$

Equation (23) implies that, due to the presence of a budget constraint, an increase in public sector employment crowds out employment in private sector.

The government chooses $L_{g}$ to maximize utility (3), subject to (23). The first-order condition of this problem gives the public sector demand for labor as a function of both wages in private and public sectors

$$
G_{\prime}\left(L_{g}\right)-w_{g}+2 \alpha\left(\bar{L}-L_{g}-L\right)\left(1-\frac{w_{g}}{w}\right)=0 .
$$

Comparing equations (24) and (8), we notice that the difference in the demand for public employment between the uncoordinated and the coordinated government economy is given by the last term, that is the marginal benefit from a reduction in the gap between actual and desired levels of total employment due to an increase in public employment. With coordinated hiring processes, this marginal benefit is reduced by the presence of the multiplicative term, with negative sign, $w_{g} / w$. This ratio, from (23), is simply the derivative of $L$ with respect to $L_{g}$, and thus indicates by how much public employment crowds out private employment. ${ }^{23}$ In particular, if the ratio is higher than one, that is in the presence of a positive wage premium in the public sector, it will be optimal for the government, as far as the second objective is concerned, to substitute private employment

\footnotetext{
${ }^{22}$ The equilibrium wage in the public sector, i.e. the value of $w_{g}$ that satisfies the first order condition (16), is indeed lower in the presence of cooperative unions if the wage elasticity of the labor demand increases with $L_{g}$.

${ }^{23}$ Algan, Cahuc and Zylberberg (2002) obtain the same result in a different model, where the crowding out effect on private employment associated with an increase in $w_{g}$ or $L_{g}$ comes from an increase in the number of active persons looking for a job in the public sector and a corresponding decrease of those looking for a job in the private sector.
} 
for public employment. Therefore, the value of $L_{g}$ that solves this problem is always lower than the one that solves the problem in a fragmented-government setting. Moreover, with respect to the case of a profit maximizer firm, here labor demand will be higher or lower, depending on whether $w_{g}$ is lower or greater than $w$.

By differentiating (24) with respect to $L_{g}$ and $w_{g}$ we obtain

$$
\frac{\partial L_{g}}{\partial w_{g}}=\frac{1+2 \alpha / w\left[\left(\bar{L}-L_{g}-L\right)-L_{g}\left(1-w_{g} / w\right)\right]}{G \prime \prime\left(L_{g}\right)-2 \alpha\left(1-w_{g} / w\right)^{2}} .
$$

In the presence of a large enough level of $\bar{L}$, and whenever $w_{g}>w$, the term in the square brackets is greater than zero, so that the demand for labor is decreasing in the wage. Furthermore, for values of the wage premium not extremely high ${ }^{24}$, the demand for labor is steeper under centralized than under fragmented government, the difference in the slope increasing with $\alpha$. As a matter of fact, the incentive for the government to expand employment in the public sector, in order to fill the gap between actual and desired level of total employment, is lower in a centralized-government economy than in a fragmented-government economy, as in the presence of centralized hiring processes the government fully recognizes the crowding out effect of public on private employment. Therefore,

in this last setting the wage elasticity of the demand for public employment is higher and closer to that resulting from a usual profit maximization problem.

\subsection{Non-cooperative union behavior}

The problem faced by the union in the private sector is to maximize (5) with respect to $w$, subject to equation (23), i.e. the labor demand in the private sector that results once the government budget constraint has been taken into account, and the government reaction function, equation (24). In both equations (23) and (24) $w_{g}$ is taken as given, as it is chosen uncooperatively by the union in the public sector.

The Lagrangian for this problem is thus

$$
\mathcal{L}=[u(w)-\bar{u}] L+\lambda\left[G \prime\left(L_{g}\right)-w_{g}+2 \alpha\left(\bar{L}-L_{g}-L\right)\left(1-\frac{w_{g}}{w}\right)\right],
$$

where $L$ is as in equation (23).

Hence, in equilibrium the wage in the private sector solves the following first-order conditions:

$$
L \quad: \quad-\frac{w_{g}}{w}[u(w)-\bar{u}]+\lambda\left[G \prime \prime\left(L_{g}\right)-2 \alpha\left(1-\frac{w_{g}}{w}\right)^{2}\right]=0,
$$

\footnotetext{
${ }^{24}$ It is easy to prove that the condition $w_{g}<2 w$ is sufficient to generate the result.
} 


$$
\begin{aligned}
& w: \quad u \prime(w) w L-[u(w)-\bar{u}] L+\lambda 2 \alpha\left[\frac{w_{g}}{w}\left(\bar{L}-L_{g}-L\right)+L\left(1-\frac{w_{g}}{w}\right)\right]=0, \\
& \lambda \quad: \quad G_{\prime}\left(L_{g}\right)-w_{g}+2 \alpha\left(\bar{L}-L_{g}-L\right)\left(1-\frac{w_{g}}{w}\right)=0 .
\end{aligned}
$$

Combining equations (27) and (28) and rearranging, we obtain

$$
\frac{u \prime(w) w}{u(w)-\bar{u}}-\left[1-2 \alpha \frac{\left(w_{g} / w\right)\left[\left(w_{g} / w\right)\left(\bar{L}-L_{g}-L\right)+L\left(1-w_{g} / w\right)\right]}{L\left[G \prime \prime\left(L_{g}\right)-2 \alpha\left(1-w_{g} / w\right)^{2}\right]}\right]=0,
$$

where the last term in squared brackets is the elasticity of the labor demand in the private sector in the presence of coordinated government behavior. It is higher than under a fragmented government, as in the presence of a centralized government there are two effects on the labor demand that the union has to take into account when increasing its wage request. The first is the usual fall in the demand for labor due to an increase in its price. The second operates through the increase in employment in the public sector, and therefore in taxes, induced by the initial decrease in employment in the private sector.

Analogously, the relevant Lagrangian for the union in the public sector is

$$
\mathcal{L}=\left[u\left(w_{g}\right)-\bar{u}\right] L_{g}+\lambda\left[G \prime\left(L_{g}\right)-w_{g}+2 \alpha\left(\bar{L}-L_{g}-L\right)\left(1-\frac{w_{g}}{w}\right)\right],
$$

where $L$ is again as in equation (23).

The first-order conditions are now:

$$
\begin{array}{cc}
L_{g}: & u\left(w_{g}\right)-\bar{u}+\lambda\left[G \prime \prime\left(L_{g}\right)-2 \alpha\left(1-\frac{w_{g}}{w}\right)^{2}\right]=0, \\
w_{g}: & u \prime\left(w_{g}\right) L_{g}-\lambda\left\{1+\frac{2 \alpha}{w}\left[\left(\bar{L}-L_{g}-L\right)-L_{g}\left(1-\frac{w_{g}}{w}\right)\right]\right\}=0, \\
\lambda: & G \prime\left(L_{g}\right)-w_{g}+2 \alpha\left(\bar{L}-L_{g}-L\right)\left(1-\frac{w_{g}}{w}\right)=0 .
\end{array}
$$

Combining equations (32) and (33) and rearranging, we obtain

$$
\frac{u \prime\left(w_{g}\right) w_{g}}{u\left(w_{g}\right)-\bar{u}}+\frac{\left.w_{g}\left\{1+(2 \alpha / w)\left[\left(\bar{L}-L_{g}-L\right)\right]-L_{g}\left(1-w_{g} / w\right)\right]\right\}}{L_{g}\left[G \prime \prime\left(L_{g}\right)-2 \alpha\left(1-w_{g} / w\right)^{2}\right]}=0,
$$

that implies again that the wage elasticity of the gain from employment and that of the labor demand in the public sector must be equal in equilibrium.

The wage elasticities of the labor demand in both the private and the public sectors are higher in a centralized government economy than in a fragmented one. ${ }^{25}$ As a consequence, both private and public sectors' equilibrium wages are lower under a centralized than under a fragmented government.

\footnotetext{
${ }^{25}$ For the public sector this is true provided that the wage premium is not excessively high (see the previous footnote).
} 
As long as the effect of centralization in the hiring process on wages is stronger in the public sector than in the private one, higher coordination among governments decreases the wage premium.

Unsurprisingly, with respect to the fragmented government case, in equilibrium wages will be lower and employment will be higher.

\subsection{Cooperative union behavior}

Finally, in the presence of coordinated public hiring process and cooperative union behavior the problem can be stated as follows. The union maximizes its utility (7) with respect to both $w$ and $w_{g}$, taking into account both private and public sector employers' reaction functions.

The Lagrangian for this problem is thus

$$
\mathcal{L}=\left[u\left(w_{g}\right)-\bar{u}\right] L_{g}+[u(w)-\bar{u}] L+\lambda\left[G \prime\left(L_{g}\right)-w_{g}+2 \alpha\left(\bar{L}-L_{g}-L\right)\left(1-\frac{w_{g}}{w}\right)\right]
$$

where $L$ is again as in equation (23).

The first-order conditions are now:

$$
\begin{array}{cc}
L_{g}: & u\left(w_{g}\right)-\bar{u}-\frac{w_{g}}{w}[u(w)-\bar{u}]+\lambda\left[G \prime \prime\left(L_{g}\right)-2 \alpha\left(1-\frac{w_{g}}{w}\right)^{2}\right]=0, \\
w_{g}: & u \prime\left(w_{g}\right) L_{g}-[u(w)-\bar{u}] \frac{L_{g}}{w}-\lambda\left\{1+\frac{2 \alpha}{w}\left[\left(\bar{L}-L_{g}-L\right)-L_{g}\left(1-\frac{w_{g}}{w}\right)\right]\right\}=0, \\
w: & u \prime(w) w-[u(w)-\bar{u}]+2 \alpha \lambda\left[\left(1-\frac{w_{g}}{w}\right)+\left(\bar{L}-L_{g}-L\right) \frac{w_{g}}{w L}\right]=0, \\
\lambda: & G \prime\left(L_{g}\right)-w_{g}+2 \alpha\left(\bar{L}-L_{g}-L\right)\left(1-\frac{w_{g}}{w}\right)=0 .
\end{array}
$$

Combining equations (37) and (38) and rearranging, we obtain

$$
\frac{u \prime\left(w_{g}\right) w_{g}-\left(w_{g} / w\right)[u(w)-\bar{u}]}{u\left(w_{g}\right)-\bar{u}-\left(w_{g} / w\right)[u(w)-\bar{u}]}+\frac{\left.w_{g}\left\{1+(2 \alpha / w)\left[\left(\bar{L}-L_{g}-L\right)\right]-L_{g}\left(1-w_{g} / w\right)\right]\right\}}{L_{g}\left[G \prime \prime\left(L_{g}\right)-2 \alpha\left(1-w_{g} / w\right)^{2}\right]}=0 .
$$

The second term in this expression is the usual wage elasticity of the public sector labor demand in a centralized government economy. The first term is the wage elasticity of the gain from employment in the public sector. It is more complicated than in a fragmented-government setting, as the union now recognizes that an increase of one unit in public sector employment reduces private employment by $w_{g} / w$ units. Moreover, a cooperative union cares about employees in both sectors. Therefore the gain from employment in the public sector is no longer equal to $u\left(w_{g}\right)-\bar{u}$ but it is smaller and equal to $u\left(w_{g}\right)-\bar{u}-\left(w_{g} / w\right)[u(w)-\bar{u}]$; analogously, the marginal gain is $u \prime\left(w_{g}\right)-[u(w)-\bar{u}] / w$ instead of $u \prime\left(w_{g}\right)$.

Hence, in equilibrium the usual condition on wage elasticities must apply.

As far as the choice of the private-sector wage is concerned, dividing equation (39) by equation (37) and rearranging we obtain the optimality condition, which can be expressed in terms of the 
usual condition on elasticities:

$$
\frac{u \prime(w) w-\left(w / w_{g}\right)\left[u\left(w_{g}\right)-\bar{u}\right]}{u(w)-\bar{u}-\left(w / w_{g}\right)\left[u\left(w_{g}\right)-\bar{u}\right]}-\left[1-2 \alpha \frac{\left(w_{g} / w\right)\left[\left(w_{g} / w\right)\left(\bar{L}-L_{g}-L\right)+L\left(1-w_{g} / w\right)\right]}{L\left[G \prime \prime\left(L_{g}\right)-2 \alpha\left(1-w_{g} / w\right)^{2}\right]}\right]=0 .
$$

The first term is the wage elasticity of the gain for the encompassing union from employment in the private sector. Notice that in this case the gain in the private sector induced by an increase of one unit in private employment, $u(w)-\bar{u}$, is reduced by the associated cost induced by a reduction of $w / w_{g}$ units in the public sector, $\left(w / w_{g}\right)\left[u\left(w_{g}\right)-\bar{u}\right]$. The last term in squared brackets is again the elasticity of the labor demand in the private sector in the presence of coordinated government behavior.

\section{A numerical simulation}

In this section we show the results of a numerical simulation. This allows us to easily describe some implications of the different institutional setups analyzed in the model.

In the simulation we assume the same technology in the private and in the public sector, i.e. $G(L)=A \log L$, and the same utility from employment in both sectors, i.e. $u(w)=w^{\beta}$ and $u\left(w_{g}\right)=w_{g}^{\beta}$. The parameters take the following values: $A=5, \alpha=0.3, \beta=0.5, \bar{u}=1, \bar{L}=3 .^{26}$

The results, as for wage and employment levels in the private and in the public sector, the wage premium, the tax rate, government's and union's utilities, under the four institutional setups are presented in Table 2. We measure the public-sector wage premium as $w_{g} / w$. The utility of the union is the sum of the utilities achieved by the unions in the private and in the public sector, even under a non-cooperative union behavior setup.

The main findings can be summarized as follows: ${ }^{27}$

(i) cooperation among unions increases wages and reduces employment in the private sector; it, generally, results in lower wages and higher employment in the public sector;

(ii) centralization in government behavior induces wage moderation and higher employment in both sectors, under non cooperative union behavior; with union cooperation the effect of centralization is ambiguous;

(iii) a public-sector wage premium may or may not occur; it decreases if unions cooperate.

\footnotetext{
${ }^{26}$ In order to obtain sensible values for the tax rate, in the numerical simulation we assume the following budget constraint: $w_{g} L_{g}=\tau w L+K$, where $K$ can be thought of as any kind of revenue that is unrelated to labor income. We set $K=4.5$. Of course, the presence of this term does not affect the equilibrium conditions.

${ }^{27}$ The solution presented here is unrestricted. If we had imposed the non-negative profit condition, we would have obtained, in the case of centralized government and cooperative unions, a finite value for the wage in the private sector $(w)$ and, consequently, positive amounts for the employment level in the private sector $(L)$, the tax rate $(\tau)$ and the wage premium, $\left(w_{g} / w\right)$.
} 
Table 2: Results of the numerical simulation

\begin{tabular}{c|cc|cc}
\hline & \multicolumn{2}{|c|}{ Fragmented government } & \multicolumn{2}{c}{ Centralized government } \\
& Non-cooperative unions & Cooperative unions & Non-cooperative unions & Cooperative unions \\
\hline$L_{g}$ & 1.235 & 1.332 & 1.392 & 1.545 \\
$w_{g}$ & 4.522 & 4.367 & 3.588 & 4.108 \\
$L$ & 0.979 & 0.65 & 1.262 & $\approx 0$ \\
$w$ & 4 & 5.675 & 3.566 & $\approx \infty$ \\
$\frac{w_{g}}{w}$ & 1.13 & 0.769 & 1.006 & $\approx 0$ \\
$\tau$ & 0.276 & 0.357 & 0.111 & 2.801 \\
$U_{u}$ & 2.37 & 2.349 & 2.367 & -6.548 \\
$U_{g}$ & -5.56 & -5.839 & -4.702 & \\
\hline
\end{tabular}


As far as welfare is concerned, the government is better off in the presence of non-cooperative union behavior, whereas the union benefits from cooperation. From the union point of view, the first best outcome is achieved under a centralized government setup with cooperative union behavior. As a matter of fact, in this situation the union, which moves first, is able to take into account all relevant information. The effect of centralization on government's utility is instead ambiguous. The government obtaines a lower disutility in the presence of a centralized hiring setup if unions do not cooperate, in the presence of a fragmented hiring setup otherwise.

\section{Empirical evidence}

In this section we present preliminary evidence on some of the implications of the theoretical model. Our focus is on estimating the effects of government fragmentation and union cooperation on wage and employment levels in both the private and the public sector. To this end we use a panel of data drawn from the 2001 OECD Economic Outlook. The sample covers the period 1960-2000 and the following countries: Australia, Austria, Belgium, Canada, Denmark, Finland, France, Germany, Ireland, Italy, Japan, Netherlands, New Zealand, Norway, Portugal, Spain, Sweden, Switzerland, UK and USA.

Accurate measures of the degree of government fragmentation and union cooperation are not available. In our framework, fragmentation means that the spending units do not internalize the budget constraint at all. This assumption is the extreme version of the well known "commonpool problem", in which spending units compete for government expenditure that are financed through broad bases taxes. Since the cost of higher spending is broadly dispersed, while the benefits (primarily higher spending on particular projects, on transfer programs or similar) are concentrated, spending units have an incentive to over-spend in the sense that they would choose lower levels of spending if they took the full cost into account. In this framework, the bias toward higher spending increases the less the spending units take into account the externality created by the general tax fund, which usually happens when the number of spending units increases and/or when the decision-making process involves more parties. Although there is evidence that measures of government fragmentation (as the number of spending ministries or the number of parties in the government coalition) are correlated with the growth of spending in European countries during the seventies and early eighties (on this see, among others, Kontopoulos and Perotti, 1999, and Volkerink and De Hann, 2001), they are not strongly correlated with the level of net borrowing over the entire sample period we consider. In what follows, therefore, as a proxy for government fragmentation we decided to use the level of total current expenditure (net of public employee 
compensations).

In our model the degree of union cooperation must be intended as the degree of centralization in wage negotiations: a cooperative union is a nationwide union that negotiates for both private and public sector employees; a non cooperative union is a union that negotiates at the sector level, where the public sector should be considered as a sector on its own. In order to measure union cooperation we rely on standard indexes of centralization in wage negotiations. In particular, we use the one presented by the OECD in the 1997 Employment Outlook and the one developed by Elmeskov, Martin and Scarpetta (1998), from now on EMS. The OECD Employment Outlook 1997 reports values for three years (1980, 1990 and 1994). EMS provide information on the development of the index for 19 OECD countries from 1980 up to the end of the 1990s. In Table 2A we report the value of the indexes in three years (1980, 1990 and 1994); when the changes in the index are described in qualitative terms by EMS (for example, an index gradually moving from 3 to 1 during the 1990s), we assume a change at the midpoint (in the example, in 1995). These indexes are constructed as sums of two different measures: the first one is the wage bargaining level (national, industry, plant); the second one is a measure of the degree of coordination among unions' (and employers') federations. This second measure captures the cooperation among unions and firms in the wage bargaining process regardless of the level at which the negotiating process take place. We will present results using also the EMS measure of the degree of cooperation.

On the basis of our model, we expect that: i) the employment level in the public sector increases as the union becomes more cooperative and, for any given level of the wage rate, decreases as the government becomes more centralized; ${ }^{28}$ ii) the employment level in the private sector decreases as the union becomes more cooperative and, at least when unions act non cooperatively, increases as the government becomes more centralized; iii) the public sector wage premium decreases with union cooperation (while no clear-cut change with government's fragmentation).

\subsection{Employment levels}

In order to explore the correlation among the relevant variables and to check whether these correlations are consistent with the predictions of the model, we estimate two separate equations for private and for public sector employment levels. Employment levels are expressed as a percentage of total population. By dividing the employment level by total population we are able to capture country differences in terms of population size and labor force while using a variable which is not dependent on the cycle (as, for example, an alternative natural candidate, such as total dependent

\footnotetext{
${ }^{28}$ The public sector labor demand in the presence of a fragmented government is shifted inward and steeper than with a centralized government. In this last case, however, unions will ask for a lower public sector wage rate and a higher employment level may result in equilibrium.
} 
employment). Employees' compensation is measured as the ratio of gross compensation, net of social security contributions ${ }^{29}$, and per-capita GDP. The normalizations of employment and compensation are important in order to reduce the heteroskedasticity in the residuals that would occur were the differences across countries in the variables in levels significant. Nominal variables, such as the fiscal variables, are expressed as percentages of GDP.

For both private and public sector employment we run the following regression:

$$
\begin{aligned}
\text { Emp }_{i t}= & \beta_{0}+\beta_{1} W_{i t}+\beta_{2} \text { Centr }_{i t}+\beta_{3} \text { Fragm }_{i t}+\beta_{4} W r * \text { Centr }_{i t}+\beta_{5} \text { Wr } * \text { Fragm }_{i t}+ \\
& \beta_{6} \text { Yrg }_{i t}+\beta_{7} \text { Ggd }_{i t}+\beta_{8} \text { Gap }_{i t}+\beta_{9} \text { Popr }_{i t}+\theta_{t}+\nu_{i}+\epsilon_{i t}
\end{aligned}
$$

where the subscripts $i$ and $t$ identify the country and the time, respectively, Emp is the (public or private) employment level as a percentage of total population, $W r$ is the average wage rate as a percentage of per-capita GDP, Centr is the index of centralization, Fragm is our measure of fragmentation, $W r * C e n t r$ is the cross term of wage rate and centralization, $W r * F r a g m$ is the cross term of wage rate and fragmentation, $Y r g$ is government's total current revenue, Ggd is government's gross debt level, Gap is the OECD measure of the output gap and Popr measures the dependency ratio (given as the ratio between total population and the population between 15 and 64 years), $\theta_{t}$ are time dummies, $\nu_{i}$ is the country fixed effect and $\epsilon_{i t}$ is the residual term.

Table $3 \mathrm{~A}$ reports some summary statistics.

Assuming fixed effect, we focus on time series variations. This is very important, since on the right hand side of our regressions we have institutional variables which are likely correlated with country specific (time invariant) unobservable characteristics. If the latter also affect the public and/or the private sector employment levels, it is very important to control for country fixed effect in order to eliminate this source of bias. Analogously, aggregate shocks that influence fiscal outcomes are likely to be correlated across countries. Year dummies can then parcel out the effects of these shocks if the latter are only partially captured by the macroeconomic variables we control for (i.e. the output gap).

We also report results obtained assuming country specific linear trends (that is substituting $\nu_{i}$ with the term $\sum_{i} \gamma_{i} \cdot t$ and dropping the time dummies $\theta_{t}$ ). This specification is meant to control for the possible bias due to the fact that the measure of employment level that we use is expressed in physical units (not in efficiency units) while the composition of public employees in terms of skills and education has changed over time and also relatively to that observed in the private sector.

\footnotetext{
${ }^{29}$ Most countries release data on compensations net of social security contributions; contributions on public employees are often consolidated and subtracted both on the revenue and on the expenditure side.
} 
Therefore, the productivity of the average public sector worker relative to the average economywide one (which is captured by the average GDP at the denominator of $W r$ ) has probably changed over time. Similarly, private sector employees may have experienced a different productivity growth with respect to the average one. The country specific trend variables certainly will capture any other trend which may characterize the data.

On top of our measures of government fragmentation, the regressions control for total current revenue and gross debt level as a fraction of GDP. Current revenue are meant to capture the amount of disposable resources (the dimension of the public sector); its level follows the cycle. Countries with high levels of debt might be constrained in their choices by the necessity to conduct fiscal consolidations; moreover, for any given level of the budget balance (difference between total revenue and expenditure), countries with a higher level of public debt may have a lower share of current expenditure to be spent on employees' compensation, as interest payments are higher.

The cross term of the wage rate and the centralization index is included in order to capture the fact that the correlation between the wage rate and the employment level depends on the degree of union cooperation. In the model, a cooperative union will set a higher private sector wage than a non cooperative one (and therefore a lower private sector employment). In so doing, it will rise the demand for public sector employees, since the government will hire employees in order to compensate for the decrease in private sector employment. Given that the production function of the public sector is concave, this higher level of public employees will increase the wage elasticity of the labor demand (see the term $G^{\prime \prime}\left(L_{g}\right)$ in equation (9) and (25)). Therefore we expect $\beta_{4}$ to be negative. For the same reason, in the private sector the wage elasticity of the labor demand should decrease $\left(\beta_{4}\right.$ positive) as the union become more cooperative. The cross term of the wage rate and the fragmentation measure is included in order to control for the fact that higher government centralization increases the labor demand elasticity both in the public and in the private sector (see section 5.1 and 5.2). Therefore we expect $\beta_{5}$ to be positive for both the private and the public sector.

The measure of the output gap is introduced to control for the cycle and in particular to correct for the possible bias introduced by the per-capita GDP normalization of the wage rate: in periods of booms we should in fact expect an increase in both employment and GDP, therefore inducing a negative correlation between the normalized wage rate and the employment level; the output gap on the right hand side should, at least partially, correct for this distortion. Finally, the measure of the dependency ratio is meant to capture the effect of the demography on employment levels.

The results, reported in Table 4A, show significant differences between the public and the private sector. First of all, whereas in the private sector there is evidence of a negative correlation between 
the wage rate and the employment level, in the public sector this correlation is much lower and positive. Although this evidence is compatible with a variety of reasons (such as the legislative constraints on layoffs of public employees), on the basis of our model there are two effects that reduce the sensitivity of the employment level to changes in the wage rate in the public sector: i) the slope of the demand curve in the public sector, which is less steep due to the fact that the government has a target unemployment level; ii) the ability of unions, when acting cooperatively, to shift out the demand for public employees through an increase in the private sector wage rate.

As argued, we use the level of government current expenditure (net of employees compensation) as a proxy of the ability of public sector decisional units to coordinate their actions. More fragmentation implies - for any given level of revenues - a higher level of expenditure. As expected, our proxy for government fragmentation is positively correlated with the level of public employment, while a negative correlation exists for the private sector.

Table 4A shows also that the employment level is increasing in the degree of centralization in the public sector, while no significant correlation exits for the private sector. This evidence is partly consistent with the prediction of our model that a cooperative union will always have the incentive to rise private sector wage rates, reducing private sector employment, since this will lead the government to increase public sector employment level (the demand shift effect).

The sensitivity of the employment to the wage rate in the public sector increases with the degree of centralization, while the relationship is not significant in the private sector (this can be seen from the coefficient of $W r * C e n t r)$. We would have expected the elasticity of the demand to decrease in the private sector: the model in fact predicts that cooperation among unions will lead to an increase in the public sector employment and to a decrease in the private sector one. As far as the second cross term is concerned ( $W r * F r a g m)$ we would have expected a positive sign for both the private and the public sector. The negative sign in the public sector regression is probably due to the specific proxy of fragmentation that we have chosen; in fact the level of current expenditure, being net of compensation, is by definition negatively correlated with the public sector wage bill (and therefore with the public sector wage rate).

The results show a positive correlation between government current revenue and the employment level in the public sector, while no significant correlation exists for the private sector. Government revenue are usually highly correlated with the cycle. In periods of downturn, revenue are low and a higher fraction of current expenditure is absorbed by the automatic stabilizers (typically unemployment benefits and transfers). On the contrary, during expansions governments need to spend less for automatic stabilizers and more resources are left to hire public employees. The debt level is negatively correlated with public employment. In fact, for any given level of deficit, a higher 
level of debt implies a lower level of expenditure other than interest payments.

Finally, the measure of the dependency ratio seems to have a positive demand effect for both public and private sector employees and this effect seems to be higher for private employment. In fact, it is not surprising that a variable capturing the effect of the demography (as the dependency ratio) over the period of analysis (1960-2000) is more correlated with the level of employment in the private than in the public sector. The measure of the output gap is positively correlated with the level of private employment; as expected, considering that the cycle affect the budget mainly through tax components, no significant correlation exists with public sector employment.

Overall, the results of Table 4A show that public employment is not very sensitive to variations in the wage rate; it increases with union cooperation and is highly correlated with fiscal measures. Private sector employment is more sensitive to the wage rate; it is less correlated with fiscal variables. Although some of these results might be not surprising, they are consistent with the model and signal relevant differences between private and public sector employment behavior.

\subsection{The public sector wage premium}

Next, we test the relationship between the public sector wage premium (i.e., the relative wage rate, $R w r)$ and a set of variables similar to the ones of the employment regressions. We run the following regression:

$$
\begin{aligned}
\text { Rwr }_{i t}= & \beta_{0}+\beta_{1} \text { Remp }_{i t}+\beta_{2} \text { Centr }_{i t}+\beta_{3} \text { Fragm }_{i t}+\beta_{4} \text { Remp }_{i t} * \text { Centr }_{i t}+\beta_{5} \text { Remp }_{i t} * \text { Fragm }_{i t}+ \\
& \beta_{6} \text { Yrg }_{i t}+\beta_{7} G g d_{i t}+\beta_{8} \text { Gap }_{i t}+\beta_{9} \text { Popr }_{i t}+\theta_{t}+\nu_{i}+\epsilon_{i t}
\end{aligned}
$$

where Remp is the ratio of the number of public employees and the number of private employees. The other variables have the same meaning as before. Also in this case we run regressions with fixed effects and country specific linear trends. Results are reported in table 7A.

The wage premium is negatively correlated with the relative employment levels. This is simply the consequence of the strong negative relationship between the wage rate and the employment level in the private sector. Moreover, the wage premium is negatively correlated with the degree of centralization: more union cooperation leads to a lower wage premium. We have already stressed that this is one important prediction of the model.

The level of total current expenditure has a negative (and significant) correlation with the premium. This is not in contrast with the model, which did not predict a clear relationship between government fragmentation and wage premium. A higher level of revenue is positively correlated 
with the premium, while the level of debt does not have a significant correlation. Finally, the output gap and the dependency ratio variable are negatively correlated with the premium.

\subsection{Robustness}

Among the indexes used in the literature, the EMS index is the most updated and more refined one (in particular, EMS reported the changes of the index over time). However, centralization indexes are rather arbitrary measures, partly based on subjective evaluations. It is therefore important to check the robustness of the results using different measures. In Table 5A,6A, 8A and 9A we run the same regressions as in Table $4 \mathrm{~A}$ and $7 \mathrm{~A}$ simply changing the measure of centralization. In particular we use also the index proposed by the OECD in the 1997 Employment Outlook and the EMS index which measure only unions and employers cooperation (EMS cooperation index).

The results show similar patterns as when using the EMS centralization index. However, when using the OECD 1997 index, the correlation between the private sector employment and centralization is positive and significant. As for the wage premium, the results using the three different centralization indexes are very similar. Only, when using the OECD 1997 index the correlation between the premium and the centralization index is not significant. It must be stressed that the OECD index covers 19 countries (Ireland is missing) and, therefore, when using it we loose some observations.

In Tables $4 \mathrm{~A}$ to $9 \mathrm{~A}$ we have reported results for three regressions: one for the public sector employment level, one for the private sector employment level and one for the wage premium. We have argued that these regressions are intended to check for correlations that should qualitatively hold in equilibrium (assuming our model is a good approximation of the economy). However, one could try to give to these regressions a more structural interpretation. For example, we could argue that the above regressions are linear conditional expectation functions (a strong assumption). In this case, in order to get unbiased estimates of the coefficients, we should take care of the endogeneity problem: in fact, the wage rate in the employment regressions is probably correlated with the level of employment; similarly, in the third regression, the relative employment rate is likely correlated with the wage premium. We therefore tried to run the same regressions instrumenting the wage rate (and the relative employment level) with its lag value. Not surprisingly, given the strong correlation over time of wage rates and employment levels, the results (not shown) are substantially the same. 


\section{Final remarks}

This paper has presented a model of wage and employment determination which distinguishes between the private and the public sector. Among the important peculiarities of the public sector labor market we focus on those implied by the public employer's objective. As a matter of fact, whereas the private sector employer can be reasonably assumed to be a profit maximizer, understanding how public employer's decisions are made is by far more complex.

We assumed that the public sector employer seeks to maximize social welfare, having primarily an efficiency goal. This goal implies that he sets employment to maximize the profit associated with the public production. Reducing the unemployment rate in the economy is also part of his efficiency goal. Wages are set in both sectors by monopoly unions.

We investigated the effects on the labor market equilibrium of different degrees of coordination in both governments' and unions' decision processes.

The analysis predicts a weaker relationship between wages and employment in the public sector than in the private sector. In particular, in our framework there are two factors that reduce the sensitivity of the employment level to the wage rate in the public sector: i) the wage elasticity of the labor demand, which for any given level of employment is lower in the public sector than in the private sector, due to the government's concern about the unemployment level in the overall economy; ii) the ability of the unions, when acting cooperatively across sectors, to shift out the demand for public employees through an increase in the private sector wage rate. In fact, a cooperative union will always have the incentive to rise wages in the private sector, thereby reducing private employment, as it knows that the government will react to lower private employment by rising the public one. This in turn implies that higher degrees of cooperation among unions increase the employment level in the public sector and decrease the wage premium. Finally, the model suggests that public employment tends to be lower (and private employment higher) in the presence of more budget conscious governments. The empirical evidence seems to support most of these predictions. 


\section{References}

Algan, Y. P. Cahuc and A. Zylberberg (2002), "Public Employment and Labour Market Performance", Economic Policy,1, 9-65.

Boeri, T. G. Nicoletti and S. Scarpetta (2000), "Regulation and Labor Market Performance", CEPR Discussion Paper No. 2420.

Ehrenberg, R. G. and J. L. Schwarz (1986), "Public-Sector Labor Markets", in O. Ashenfelter and R. Layard (eds.), Handbook of Labor Economics, Volume II, Amsterdam, The Netherlands, Elsevier Science Publishers.

Elmeskov, J. J. P. Martin and S. Scarpetta (1998), "Key lessons for labor market reforms: evidence from OECD countries' experiences", Swedish Economic Policy Review, 5, 205-252.

Farber, H. S. (1986), "The Analysis of Union Behavior", in O. Ashenfelter and R. Layard (eds.), Handbook of Labor Economics, Volume II, Amsterdam, The Netherlands, Elsevier Science Publishers.

Forni, L. (2002), "Centralization of Wage Bargaining and the Unemployment Rate: Revisiting the Humpshape Hypothesis", Temi di Discussione n. 487, Banca d'Italia.

Gregory, R. G. and J. Borland (1999), "Recent Developments in Public Sector Labor Markets", in O. Ashenfelter and D. Card (eds.), Handbook of Labor Economics, Volume III, Amsterdam, The Netherlands, Elsevier Science Publishers.

Heller, P. S. and A. A. Tait (1983), "Government Employment and Pay: Some International Comparisons", in Document of International Monetary Fund, Occasional Paper No. 24.

Holmlund, B. (1993), "Wage setting in private and public sectors in a model with endogenous government behavior", European Journal of Political Economy, 9, 149-162.

Holmlund, B. (1997), "Macroeconomic Implications of Cash Limits in the Public Sector", Economica, 64, 49-62.

Kontopoulos, Y. and R. Perotti (1999), "Government Fragmentation and Fiscal Policy Outcomes: Evidence from OECD Countries", in J. M. Poterba and J.1 von Hagen, Fiscal Institutions and Fiscal Performance, NBER Conference Report, Chicago and London, The University of Chicago Press.

McDonald, I. M. and R. M. Solow (1981), "Wage bargaining and employment", American Economic Review, 71, 896-908.

O'Brien, K. (1994), "The impact of union political activities on public-sector pay, employment and budgets", Industrial Relations, 33, 322-345.

OECD (1997), Employment Outlook, Paris.

Portugal, P. and M. Centeno (2001), "Wages of Civil Servants", in Banco de Portugal, Economic Bullettin, September.

Volkerink B. and J. De Haan (2001), "Fragmented Government Effects on Fiscal Policy", Public Choice, 109, 221-242. 


\section{APPENDIX}

\section{Table 1A: Public employees}

Public employees as a percentage of total dependent employees

\begin{tabular}{lcccccc}
\hline & 1960 & 1970 & 1980 & 1990 & 1995 & 2000 \\
\hline Italy & $14.7 \%$ & $17.1 \%$ & $20.7 \%$ & $22.4 \%$ & $22.9 \%$ & $21.1 \%$ \\
Germany & $10.5 \%$ & $13.5 \%$ & $16.5 \%$ & $16.9 \%$ & $14.3 \%$ & $12.8 \%$ \\
France & -- & $22.2 \%$ & $24.2 \%$ & $26.1 \%$ & $27.7 \%$ & $26.6 \%$ \\
Spain & -- & $6.7 \%$ & $12.3 \%$ & $16.1 \%$ & $17.9 \%$ & $16.5 \%$ \\
& & & & & & \\
Euro 11 & -- & - & $19.3 \%$ & $21.1 \%$ & $20.6 \%$ & $19.1 \%$ \\
& -- & $19.9 \%$ & $23.7 \%$ & $27.1 \%$ & $28.3 \%$ & $26.7 \%$ \\
UK & & & & & & \\
USA & $14.9 \%$ & $17.4 \%$ & $17.7 \%$ & $16.5 \%$ & $16.2 \%$ & $15.4 \%$ \\
Japan & -- & $11.9 \%$ & $12.3 \%$ & $10.5 \%$ & $10.2 \%$ & $10.2 \%$ \\
Canada & -- & $24.1 \%$ & $23.5 \%$ & $25.0 \%$ & $26.0 \%$ & $24.3 \%$ \\
\hline
\end{tabular}

Public employees as a percentage of total employed

\begin{tabular}{lcccccc}
\hline & 1960 & 1970 & 1980 & 1990 & 1995 & 2000 \\
\hline Italy & $9.0 \%$ & $12.2 \%$ & $15.4 \%$ & $17.3 \%$ & $18.0 \%$ & $16.7 \%$ \\
Germany & $8.1 \%$ & $11.2 \%$ & $14.6 \%$ & $15.1 \%$ & $12.8 \%$ & $11.5 \%$ \\
France & -- & $17.6 \%$ & $20.4 \%$ & $23.1 \%$ & $24.9 \%$ & $24.3 \%$ \\
Spain & -- & $4.9 \%$ & $9.3 \%$ & $13.8 \%$ & $15.5 \%$ & $14.3 \%$ \\
& & & & & & \\
Euro 11 & -- & $11.8 \%$ & $15.2 \%$ & $17.1 \%$ & $16.9 \%$ & $15.8 \%$ \\
UK & -- & $18.3 \%$ & $21.6 \%$ & $22.9 \%$ & $24.2 \%$ & $23.4 \%$ \\
& & & & & & \\
USA & $12.7 \%$ & $16.0 \%$ & $16.4 \%$ & $15.4 \%$ & $15.4 \%$ & $15.2 \%$ \\
Japan & -- & $7.7 \%$ & $8.8 \%$ & $8.1 \%$ & $8.3 \%$ & $8.4 \%$ \\
Canada & -- & $20.7 \%$ & $20.4 \%$ & $21.5 \%$ & $21.9 \%$ & $20.2 \%$ \\
\hline
\end{tabular}

Source: OECD Economic Outlook database, 2001 
Table 2A: Centralization Indexes

\begin{tabular}{|c|c|c|c|c|}
\hline$\overline{\text { Country }}$ & Year & OECD (1997) & EMS (1998) & $\begin{array}{c}\text { EMS (1998) } \\
\text { Coordination }\end{array}$ \\
\hline \multirow[t]{3}{*}{ Austria } & 1980 & 3 & 3 & 3 \\
\hline & 1990 & 3 & 3 & 3 \\
\hline & 1994 & 3 & 3 & 3 \\
\hline \multirow[t]{3}{*}{ Denmark } & 1980 & 3 & 3 & 3 \\
\hline & 1990 & 2 & 3 & 3 \\
\hline & 1994 & 2 & 3 & 3 \\
\hline \multirow[t]{3}{*}{ Finland } & 1980 & 3 & 3 & 2 \\
\hline & 1990 & 3 & 2 & 2 \\
\hline & 1994 & 3 & 2 & 2 \\
\hline \multirow[t]{3}{*}{ Norway } & 1980 & 3 & 3 & 3 \\
\hline & 1990 & 3 & 3 & 3 \\
\hline & 1994 & 3 & 3 & 3 \\
\hline \multirow[t]{3}{*}{ Sweden } & 1980 & 3 & 3 & 3 \\
\hline & 1990 & 3 & 2 & 1 \\
\hline & 1994 & 2 & 2 & 2 \\
\hline \multirow[t]{3}{*}{ Australia } & 1980 & 3 & 2 & 2 \\
\hline & 1990 & 3 & 1 & 1 \\
\hline & 1994 & 1 & 1 & 1 \\
\hline \multirow[t]{3}{*}{ Belgium } & 1980 & 2 & 2 & 2 \\
\hline & 1990 & 2 & 2 & 2 \\
\hline & 1994 & 2 & 2 & 2 \\
\hline \multirow[t]{3}{*}{ Germany } & 1980 & 3 & 3 & 3 \\
\hline & 1990 & 3 & 3 & 3 \\
\hline & 1994 & 3 & 3 & 3 \\
\hline \multirow[t]{3}{*}{ Netherlands } & 1980 & 2 & 2 & 2 \\
\hline & 1990 & 2 & 3 & 3 \\
\hline & 1994 & 2 & 3 & 3 \\
\hline \multirow[t]{3}{*}{ New Zealand } & 1980 & 1 & 2 & 1 \\
\hline & 1990 & 1 & 2 & 1 \\
\hline & 1994 & 1 & 1 & 1 \\
\hline \multirow[t]{3}{*}{ Canada } & 1980 & 1 & 1 & 1 \\
\hline & 1990 & 1 & 1 & 1 \\
\hline & 1994 & 1 & 1 & 1 \\
\hline \multirow[t]{3}{*}{ France } & 1980 & 1 & 2 & 2 \\
\hline & 1990 & 2 & 2 & 2 \\
\hline & 1994 & 2 & 2 & 2 \\
\hline \multirow[t]{3}{*}{ Italy } & 1980 & 1 & 1 & 2 \\
\hline & 1990 & 1 & 1 & 2 \\
\hline & 1994 & 3 & 3 & 3 \\
\hline \multirow[t]{3}{*}{ Japan } & 1980 & 2 & 1 & 3 \\
\hline & 1990 & 2 & 1 & 3 \\
\hline & 1994 & 2 & 1 & 3 \\
\hline \multirow[t]{3}{*}{ Switzerland } & 1980 & 2 & -- & -- \\
\hline & 1990 & 2 & -- & -- \\
\hline & 1994 & 2 & -- & -- \\
\hline \multirow[t]{3}{*}{ UK } & 1980 & 1 & 2 & 1 \\
\hline & 1990 & 1 & 1 & 1 \\
\hline & 1994 & 1 & 1 & 1 \\
\hline \multirow[t]{3}{*}{ US } & 1980 & 1 & 1 & 1 \\
\hline & 1990 & 1 & 1 & 1 \\
\hline & 1994 & 1 & 1 & 1 \\
\hline
\end{tabular}


Table 3A: Summary statistics

\begin{tabular}{lccccc}
\hline Variable & Observations & Mean & $\begin{array}{c}\text { Standard } \\
\text { Deviations }\end{array}$ & Min & Max \\
\hline Public employment (EG) & & & & & \\
Private employment (EEP) & 742 & 0.07 & 0.03 & 0.02 & 0.17 \\
Relative employment (EMR) & 669 & 0.29 & 0.04 & 0.18 & 0.41 \\
Wage rate public (WRG) & 701 & 0.26 & 0.11 & 0.07 & 0.60 \\
Wage rate private (WR) & 673 & 1.81 & 0.65 & 0.69 & 5.62 \\
Wage premium (WAR) & 600 & 1.19 & 0.20 & 0.80 & 1.98 \\
Government current expenditure (YPG) & 607 & 1.53 & 0.52 & 0.50 & 4.78 \\
Government current expenditure excluding & 637 & 0.378 & 0.106 & 0.114 & 0.648 \\
employees compensation (YPGW) & 632 & 0.264 & 0.086 & 0.062 & 0.461 \\
Government current revenue (YRG) & 631 & 0.39 & 0.09 & 0.17 & 0.58 \\
Government gross debt (GGFL) & 530 & 0.57 & 0.26 & 0.10 & 1.34 \\
Output gap (GAP) & 598 & -0.54 & 2.57 & -11.31 & 7.30 \\
Dependency ratio (POP) & 750 & 1.53 & 0.08 & 1.31 & 1.74 \\
\hline
\end{tabular}


Table 4A: Regression results (EMS 1998 Centralization Index)

\begin{tabular}{|c|c|c|c|c|c|c|c|c|}
\hline \multirow{3}{*}{ Dependent variable } & \multicolumn{4}{|c|}{ Fixed effects } & \multicolumn{4}{|c|}{ Country specific trend } \\
\hline & \multicolumn{2}{|c|}{$\begin{array}{l}\text { Public sector } \\
\text { employment }\end{array}$} & \multicolumn{2}{|c|}{$\begin{array}{l}\text { Private sector } \\
\text { employment }\end{array}$} & \multicolumn{2}{|c|}{$\begin{array}{l}\text { Public sector } \\
\text { employment }\end{array}$} & \multicolumn{2}{|c|}{$\begin{array}{l}\text { Private sector } \\
\text { employment }\end{array}$} \\
\hline & Coeff. & t-stat & Coeff. & t-stat & Coeff. & t-stat & Coeff. & t-stat \\
\hline Wage rate $(\mathrm{Wr})$ & 0.020 & 4.270 & -0.273 & -13.630 & 0.015 & 3.640 & -0.260 & -13.450 \\
\hline Centralization Index (Centr) & 0.012 & 4.440 & 0.005 & 0.750 & 0.009 & 3.490 & 0.000 & 0.030 \\
\hline $\begin{array}{l}\text { Government current expenditure excluding } \\
\text { employees compensation (Ypgw) }\end{array}$ & 0.252 & 9.520 & -0.980 & -10.480 & 0.284 & 12.150 & -0.828 & -9.520 \\
\hline Cross term (Wr*Centr) & -0.007 & -5.840 & -0.005 & -0.900 & -0.005 & -4.680 & -0.001 & -0.140 \\
\hline Cross term (Wr*Ypgw) & -0.105 & -7.220 & 0.712 & 10.910 & -0.095 & -7.750 & 0.647 & 10.500 \\
\hline Government current revenue (Yrgr) & 0.155 & 9.160 & -0.029 & -0.760 & 0.140 & 9.460 & -0.006 & -0.160 \\
\hline Gross government debt (Ggd) & -0.031 & -10.530 & -0.013 & -1.810 & -0.035 & -13.960 & -0.020 & -3.110 \\
\hline Output gap (Gap) & 0.000 & -0.740 & 0.001 & 3.370 & 0.000 & 0.520 & 0.002 & 5.270 \\
\hline Dependency ratio (Popr) & 0.034 & 2.530 & 0.168 & 5.150 & 0.009 & 0.840 & 0.115 & 4.010 \\
\hline Constant & -0.087 & -4.310 & 0.372 & 8.150 & -0.242 & -1.450 & -3.282 & -8.810 \\
\hline \multicolumn{9}{|l|}{ R-squared } \\
\hline within & 0.800 & & 0.742 & & & & & \\
\hline between & 0.756 & & 0.030 & & & & & \\
\hline overall & 0.729 & & 0.044 & & 0.983 & & 0.940 & \\
\hline Number of observations & 421 & & 404 & & 421 & & 404 & \\
\hline
\end{tabular}


Table 5A: Regression results (OECD Employment Outlook 1997)

\begin{tabular}{|c|c|c|c|c|c|c|c|c|}
\hline & \multicolumn{4}{|c|}{ Fixed effects } & \multicolumn{4}{|c|}{ Country specific trend } \\
\hline \multirow[t]{3}{*}{ Dependent variable } & \multicolumn{2}{|c|}{$\begin{array}{l}\text { Public sector } \\
\text { employment }\end{array}$} & \multicolumn{2}{|c|}{$\begin{array}{l}\text { Private sector } \\
\text { employment }\end{array}$} & \multicolumn{2}{|c|}{$\begin{array}{l}\text { Public sector } \\
\text { employment }\end{array}$} & \multicolumn{2}{|c|}{$\begin{array}{c}\text { Private sector } \\
\text { employment }\end{array}$} \\
\hline & Coeff. & t-stat & Coeff. & t-stat & Coeff. & t-stat & Coeff. & t-stat \\
\hline & 0.025 & 5.040 & -0.281 & -13.530 & 0.019 & 4.910 & -0.262 & -13.020 \\
\hline Centralization Index (Centr) & 0.019 & 6.810 & 0.017 & 2.080 & 0.017 & 6.880 & 0.016 & 1.990 \\
\hline $\begin{array}{l}\text { Government current expenditure excluding } \\
\text { employees compensation (Ypgw) }\end{array}$ & 0.260 & 9.320 & -1.091 & -11.780 & 0.268 & 11.200 & -0.939 & -10.640 \\
\hline Cross term (Wr*Centr) & -0.011 & -6.580 & -0.018 & -2.400 & -0.010 & -6.510 & -0.017 & -2.300 \\
\hline Cross term (Wr*Ypgw) & -0.098 & -6.320 & 0.798 & 12.210 & -0.082 & -6.220 & 0.733 & 11.450 \\
\hline Government current revenue (Yrgr) & 0.154 & 8.850 & -0.011 & -0.290 & 0.129 & 8.680 & 0.011 & 0.300 \\
\hline Gross government debt (Ggd) & -0.032 & -10.800 & -0.007 & -0.940 & -0.037 & -15.140 & -0.016 & -2.450 \\
\hline Output gap (Gap) & 0.000 & -0.510 & 0.001 & 1.960 & 0.000 & 0.340 & 0.001 & 3.930 \\
\hline Dependency ratio (Popr) & 0.013 & 0.960 & 0.186 & 5.640 & 0.009 & 0.780 & 0.123 & 4.260 \\
\hline Constant & -0.066 & -3.490 & 0.356 & 7.760 & -0.368 & -2.240 & -3.053 & -8.000 \\
\hline \multicolumn{9}{|l|}{ R-squared } \\
\hline within & 0.808 & & 0.743 & & & & & \\
\hline between & 0.736 & & 0.132 & & & & & \\
\hline overall & 0.722 & & 0.008 & & 0.984 & & 0.935 & \\
\hline Number of observations & 401 & & 384 & & 401 & & 384 & \\
\hline
\end{tabular}


Table 6A: Regression results (EMS 1998 Only Coordination Index)

\begin{tabular}{|c|c|c|c|c|c|c|c|c|}
\hline \multirow{3}{*}{ Dependent variable } & \multicolumn{4}{|c|}{ Fixed effects } & \multicolumn{4}{|c|}{ Country specific trend } \\
\hline & \multicolumn{2}{|c|}{$\begin{array}{l}\text { Public sector } \\
\text { employment }\end{array}$} & \multicolumn{2}{|c|}{$\begin{array}{c}\text { Private sector } \\
\text { employment }\end{array}$} & \multicolumn{2}{|c|}{$\begin{array}{l}\text { Public sector } \\
\text { employment }\end{array}$} & \multicolumn{2}{|c|}{$\begin{array}{c}\text { Private sector } \\
\text { employment }\end{array}$} \\
\hline & Coeff. & t-stat & Coeff. & t-stat & Coeff. & t-stat & Coeff. & t-stat \\
\hline Wage rate $(\mathrm{Wr})$ & 0.023 & 4.590 & -0.266 & -12.300 & 0.017 & 3.780 & -0.257 & -12.440 \\
\hline Centralization Index (Centr) & 0.007 & 3.390 & 0.004 & 0.530 & 0.005 & 2.340 & -0.001 & -0.110 \\
\hline $\begin{array}{l}\text { Government current expenditure excluding } \\
\text { employees compensation (Ypgw) }\end{array}$ & 0.259 & 9.710 & -0.967 & -10.980 & 0.291 & 12.290 & -0.825 & -9.980 \\
\hline Cross term (Wr*Centr) & -0.006 & -5.540 & -0.005 & -0.950 & -0.004 & -4.170 & -0.001 & -0.160 \\
\hline Cross term (Wr*Ypgw) & -0.118 & -8.080 & 0.694 & 11.660 & -0.105 & -8.440 & 0.643 & 11.230 \\
\hline Government current revenue (Yrgr) & 0.156 & 9.630 & -0.032 & -0.870 & 0.141 & 9.700 & -0.008 & -0.230 \\
\hline Gross government debt (Ggd) & -0.029 & -10.140 & -0.012 & -1.760 & -0.034 & -13.660 & -0.020 & -3.090 \\
\hline Output gap (Gap) & 0.000 & -0.910 & 0.001 & 3.220 & 0.000 & 0.320 & 0.002 & 5.120 \\
\hline Dependency ratio (Popr) & 0.019 & 1.490 & 0.160 & 4.900 & -0.003 & -0.270 & 0.112 & 3.830 \\
\hline Constant & -0.060 & -3.220 & 0.381 & 8.350 & -0.182 & -1.100 & -3.292 & -8.870 \\
\hline \multicolumn{9}{|l|}{ R-squared } \\
\hline within & 0.800 & & 0.743 & & & & & \\
\hline between & 0.792 & & 0.028 & & & & & \\
\hline overall & 0.767 & & 0.048 & & 0.983 & & 0.940 & \\
\hline Number of observations & 421 & & 404 & & 421 & & 404 & \\
\hline
\end{tabular}


Table 7A: Regression results (EMS 1998 Centralization Index)

\begin{tabular}{|c|c|c|c|c|}
\hline & \multicolumn{4}{|c|}{ Wage premium } \\
\hline \multirow[t]{2}{*}{ Dependent variable } & \multicolumn{2}{|c|}{ Fixed effects } & \multicolumn{2}{|c|}{ Country specific trend } \\
\hline & Coeff. & t-stat & Coeff. & t-stat \\
\hline Relative employment level (Remp) & -6.345 & -8.860 & -6.284 & -9.970 \\
\hline Centralization Index (Centr) & -0.238 & -5.790 & -0.229 & -5.890 \\
\hline $\begin{array}{l}\text { Government current expenditure excluding } \\
\text { employees compensation (Ypgw) }\end{array}$ & -3.339 & -4.880 & -2.830 & -5.840 \\
\hline Cross term (Remp*Centr) & 0.859 & 6.050 & 0.867 & 6.460 \\
\hline Cross term (Remp*Ypgw) & 6.205 & 4.520 & 5.993 & 5.350 \\
\hline Government current revenue (Yrgr) & 2.948 & 8.690 & 2.424 & 8.070 \\
\hline Gross government debt $(\mathrm{Ggd})$ & 0.049 & 0.680 & -0.021 & -0.350 \\
\hline Output gap (Gap) & -0.012 & -4.200 & -0.011 & -4.790 \\
\hline Dependency ratio (Popr) & -0.559 & -2.580 & -0.261 & -1.430 \\
\hline Constant & 3.358 & 8.680 & 4.002 & 1.420 \\
\hline \multicolumn{5}{|l|}{ R-squared } \\
\hline within & 0.400 & & & \\
\hline between & 0.173 & & & \\
\hline overall & 0.231 & & 0.942 & \\
\hline Number of observations & 404 & & 404 & \\
\hline
\end{tabular}


Table 8A: Regression results (OECD Employment Outlook 1997)

\begin{tabular}{|c|c|c|c|c|}
\hline & \multicolumn{4}{|c|}{ Wage premium } \\
\hline \multirow[t]{2}{*}{ Dependent variable } & \multicolumn{2}{|c|}{ Fixed effects } & \multicolumn{2}{|c|}{ Country specific trend } \\
\hline & Coeff. & t-stat & Coeff. & t-stat \\
\hline Relative employment level (Remp) & -3.569 & -5.440 & -3.636 & -6.050 \\
\hline Centralization Index (Centr) & -0.034 & -0.740 & -0.020 & -0.470 \\
\hline $\begin{array}{l}\text { Government current expenditure excluding } \\
\text { employees compensation (Ypgw) }\end{array}$ & -2.483 & -3.390 & -2.370 & -4.330 \\
\hline Cross term (Remp*Centr) & 0.220 & 1.660 & 0.196 & 1.550 \\
\hline Cross term (Remp*Ypgw) & 3.496 & 2.410 & 3.945 & 3.230 \\
\hline Government current revenue (Yrgr) & 2.864 & 7.880 & 2.441 & 7.560 \\
\hline Gross government debt (Ggd) & 0.027 & 0.350 & -0.005 & -0.080 \\
\hline Output gap (Gap) & -0.014 & -4.260 & -0.013 & -4.900 \\
\hline Dependency ratio (Popr) & -0.568 & -2.360 & -0.180 & -0.890 \\
\hline Constant & 2.661 & 5.990 & 5.245 & 1.730 \\
\hline \multicolumn{5}{|l|}{ R-squared } \\
\hline within & 0.319 & & & \\
\hline between & 0.234 & & & \\
\hline overall & 0.303 & & 0.938 & \\
\hline Number of observations & 384 & & 384 & \\
\hline
\end{tabular}


Table 9A: Regression results (EMS 1998 Only Coordination Index)

\begin{tabular}{|c|c|c|c|c|}
\hline & \multicolumn{4}{|c|}{ Wage premium } \\
\hline \multirow[t]{2}{*}{ Dependent variable } & \multicolumn{2}{|c|}{ Fixed effects } & \multicolumn{2}{|c|}{ Country specific trend } \\
\hline & Coeff. & t-stat & Coeff. & t-stat \\
\hline Relative employment level (Remp) & -5.631 & -8.580 & -5.645 & -9.610 \\
\hline Centralization Index (Centr) & -0.243 & -5.750 & -0.240 & -5.940 \\
\hline $\begin{array}{l}\text { Government current expenditure excluding } \\
\text { employees compensation (Ypgw) }\end{array}$ & -3.575 & -5.210 & -3.092 & -6.350 \\
\hline Cross term (Remp*Centr) & 0.615 & 5.360 & 0.625 & 5.710 \\
\hline Cross term (Remp*Ypgw) & 5.616 & 4.120 & 5.543 & 4.960 \\
\hline Government current revenue (Yrgr) & 3.200 & 9.610 & 2.738 & 9.210 \\
\hline Gross government debt (Ggd) & 0.052 & 0.730 & -0.010 & -0.170 \\
\hline Output gap (Gap) & -0.014 & -4.750 & -0.014 & -5.600 \\
\hline Dependency ratio (Popr) & -0.632 & -2.920 & -0.368 & -2.020 \\
\hline Constant & 3.362 & 8.610 & 4.080 & 1.440 \\
\hline \multicolumn{5}{|l|}{ R-squared } \\
\hline within & 0.394 & & & \\
\hline between & 0.191 & & & \\
\hline overall & 0.248 & & 0.941 & \\
\hline Number of observations & 404 & & 404 & \\
\hline
\end{tabular}




\section{CESifo Working Paper Series}

(for full list see www.cesifo.de)

1019 Peter Fredriksson and Bertil Holmlund, Optimal Unemployment Insurance Design: Time Limits, Monitoring, or Workfare?, August 2003

1020 Kashif S. Mansori, Following in their Footsteps: Comparing Interest Parity Conditions in Central European Economies to the Euro Countries, August 2003

1021 Christoph Borgmann and Matthias Heidler, Demographics and Volatile Social Security Wealth: Political Risks of Benefit Rule Changes in Germany, August 2003

1022 Kjell Erik Lommerud, Bjørn Sandvik and Odd Rune Staume, Good Jobs, Bad Jobs and Redistribution, August 2003

1023 Patrick Karl O'Brien, The Governance of Globalization: The Political Economy of Anglo-American Hegemony, 1793-2003, September 2003

1024 Antonio Ciccone and Giovanni Peri, Skills' Substitutability and Technological Progress: U.S. States 1950-1990, September 2003

1025 Bjørn Sandvik, Optimal Taxation and Normalisations, September 2003

1026 Massimo Bordignon and Gilberto Turati, Bailing Out Expectations and Health Expenditure in Italy, September 2003

1027 José A. Herce, Namkee Ahn, Ricard Génova, and Joaquín Pereira, Bio-Demographic and Health Aspects of Ageing in the EU, September 2003

1028 John Komlos and Marieluise Baur, From the Tallest to (One of) the Fattest: The Enigmatic Fate of the American Population in the $20^{\text {th }}$ Century, September 2003

1029 Stefan Napel and Mika Widgrén, Bargaining and Distribution of Power in the EU's Conciliation Committee, September 2003

1030 Kai Li and Dale J. Poirier, Relationship Between Maternal Behavior During Pregnancy, Birth Outcome, and Early Childhood Development: An Exploratory Study, September 2003

1031 Ivar Ekeland, James J. Heckman, and Lars Nesheim, Identifcation and Estimation of Hedonic Models, September 2003

1032 Kjetil Bjorvatn and Alexander W. Cappelen, Decentralization and the Fate of Minorities, September 2003

1033 Lars-Erik Borge and Jørn Rattsø, The Relationships Between Costs and User Charges: The Case of a Norwegian Utility Service, September 2003 
1034 Maureen Were and Nancy N. Nafula, An Assessment of the Impact of HIV/AIDS on Economic Growth: The Case of Kenya, September 2003

1035 A. Lans Bovenberg, Tax Policy and Labor Market Performance, September 2003

1036 Peter Birch Sørensen, Neutral Taxation of Shareholder Income: A Norwegian Tax Reform Proposal, September 2003

1037 Roberta Dessi and Sheilagh Ogilvie, Social Capital and Collusion: The Case of Merchant Guilds, September 2003

1038 Alessandra Casarico and Carlo Devillanova, Capital-skill Complementarity and the Redistributive Effects of Social Security Reform, September 2003

1039 Assaf Razin and Efraim Sadka, Privatizing Social Security Under Balanced-Budget Constraints: A Political-Economy Approach, September 2003

1040 Michele Moretto, Paolo M. Panteghini, and Carlo Scarpa, Investment Size and Firm's Value under Profit Sharing Regulation, September 2003

1041 A. Lans Bovenberg and Peter Birch Sørensen, Improving the Equity-Efficiency Tradeoff: Mandatory Savings Accounts for Social Insurance, September 2003

1042 Bas van Aarle, Harry Garretsen, and Florence Huart, Transatlantic Monetary and Fiscal Policy Interaction, September 2003

1043 Jerome L. Stein, Stochastic Optimal Control Modeling of Debt Crises, September 2003

1044 Thomas Stratmann, Tainted Money? Contribution Limits and the Effectiveness of Campaign Spending, September 2003

1045 Marianna Grimaldi and Paul De Grauwe, Bubbling and Crashing Exchange Rates, September 2003

1046 Assar Lindbeck and Dennis J. Snower, The Firm as a Pool of Factor Complementarities, September 2003

1047 Volker Grossmann, Firm Size and Diversification: Asymmetric Multiproduct Firms under Cournot Competition, September 2003

1048 Dan Anderberg, Insiders, Outsiders, and the Underground Economy, October 2003

1049 Jose Apesteguia, Steffen Huck and Jörg Oechssler, Imitation - Theory and Experimental Evidence, October 2003

1050 G. Abío, G. Mahieu and C. Patxot, On the Optimality of PAYG Pension Systems in an Endogenous Fertility Setting, October 2003

1051 Carlos Fonseca Marinheiro, Output Smoothing in EMU and OECD: Can We Forego Government Contribution? A Risk Sharing Approach, October 2003 
1052 Olivier Bargain and Nicolas Moreau, Is the Collective Model of Labor Supply Useful for Tax Policy Analysis? A Simulation Exercise, October 2003

1053 Michael Artis, Is there a European Business Cycle?, October 2003

1054 Martin R. West and Ludger Wößmann, Which School Systems Sort Weaker Students into Smaller Classes? International Evidence, October 2003

1055 Annette Alstadsaeter, Income Tax, Consumption Value of Education, and the Choice of Educational Type, October 2003

1056 Ansgar Belke and Ralph Setzer, Exchange Rate Volatility and Employment Growth: Empirical Evidence from the CEE Economies, October 2003

1057 Carsten Hefeker, Structural Reforms and the Enlargement of Monetary Union, October 2003

1058 Henning Bohn and Charles Stuart, Voting and Nonlinear Taxes in a Stylized Representative Democracy, October 2003

1059 Philippe Choné, David le Blanc and Isabelle Robert-Bobée, Female Labor Supply and Child Care in France, October 2003

1060 V. Anton Muscatelli, Patrizio Tirelli and Carmine Trecroci, Fiscal and Monetary Policy Interactions: Empirical Evidence and Optimal Policy Using a Structural New Keynesian Model, October 2003

1061 Helmuth Cremer and Pierre Pestieau, Wealth Transfer Taxation: A Survey, October 2003

1062 Henning Bohn, Will Social Security and Medicare Remain Viable as the U.S. Population is Aging? An Update, October 2003

1063 James M. Malcomson, Health Service Gatekeepers, October 2003

1064 Jakob von Weizsäcker, The Hayek Pension: An efficient minimum pension to complement the welfare state, October 2003

1065 Joerg Baten, Creating Firms for a New Century: Determinants of Firm Creation around 1900, October 2003

1066 Christian Keuschnigg, Public Policy and Venture Capital Backed Innovation, October 2003

1067 Thomas von Ungern-Sternberg, State Intervention on the Market for Natural Damage Insurance in Europe, October 2003

1068 Mark V. Pauly, Time, Risk, Precommitment, and Adverse Selection in Competitive Insurance Markets, October 2003 
1069 Wolfgang Ochel, Decentralising Wage Bargaining in Germany - A Way to Increase Employment?, November 2003

1070 Jay Pil Choi, Patent Pools and Cross-Licensing in the Shadow of Patent Litigation, November 2003

1071 Martin Peitz and Patrick Waelbroeck, Piracy of Digital Products: A Critical Review of the Economics Literature, November 2003

1072 George Economides, Jim Malley, Apostolis Philippopoulos, and Ulrich Woitek, Electoral Uncertainty, Fiscal Policies \& Growth: Theory and Evidence from Germany, the UK and the US, November 2003

1073 Robert S. Chirinko and Julie Ann Elston, Finance, Control, and Profitability: The Influence of German Banks, November 2003

1074 Wolfgang Eggert and Martin Kolmar, The Taxation of Financial Capital under Asymmetric Information and the Tax-Competition Paradox, November 2003

1075 Amihai Glazer, Vesa Kanniainen, and Panu Poutvaara, Income Taxes, Property Values, and Migration, November 2003

1076 Jonas Agell, Why are Small Firms Different? Managers’ Views, November 2003

1077 Rafael Lalive, Social Interactions in Unemployment, November 2003

1078 Jean Pisani-Ferry, The Surprising French Employment Performance: What Lessons?, November 2003

1079 Josef Falkinger, Attention, Economies, November 2003

1080 Andreas Haufler and Michael Pflüger, Market Structure and the Taxation of International Trade, November 2003

1081 Jonas Agell and Helge Bennmarker, Endogenous Wage Rigidity, November 2003

1082 Fwu-Ranq Chang, On the Elasticities of Harvesting Rules, November 2003

1083 Lars P. Feld and Gebhard Kirchgässner, The Role of Direct Democracy in the European Union, November 2003

1084 Helge Berger, Jakob de Haan and Robert Inklaar, Restructuring the ECB, November 2003

1085 Lorenzo Forni and Raffaela Giordano, Employment in the Public Sector, November 2003 